\title{
Financial Development, Business Cycle and Bank Risk in Southeast Asian Countries*
}

\author{
Son Hung TRAN"*, Liem Thanh NGUYEN ${ }^{* * *}$ \\ Received: December 12, 2019 Revised: February 06, 2020 Accepted: February 07, 2020.
}

\begin{abstract}
The paper aims to examine whether business cycles affect the link between financial development and bank risk, measured by Zscore and nonperforming loans to total loans in six Southeast Asian countries, namely Indonesia, Philippines, Malaysia, Singapore, Thailand and Vietnam. This study uses a sample of 95 listed commercial banks over a 15-year period between 2004 and 2018 in the six Southeast Asian countries. This study employs panel OLS regression and modifications to tackle issues such as endogeneity and heteroscedasticity. The results show that the impact of stock market development (the ratio of the market capitalization to GDP) on Zscore is significantly positive, whereas its effect on non-performing loans is significantly negative. The findings suggest that financial development, in terms of stock market capitalization, improves banks' Zscores and reduces their level of non-performing loans, suggesting that financial development on average reduces bank risk. The impact of business cycle is insignificant towards bank risk, thus rejecting both counter- and pro-cyclical hypotheses, except for the case of risk indicator of loan loss provisions. Examining the joint effect of the business cycle and financial development on bank risk, we find that the phase of business cycles generally does not moderate the link between financial development and bank risk.
\end{abstract}

Keywords: Bank Risk, Business Cycle, Financial Development, South-East Asian Countries, Listed Banks

JEL Classification Code: G15; E22; O16

\section{Introduction}

Financial sector plays a vital role in a country's economy, and previous empirical studies indicate that financial development has a positive impact on economic activities of a certain country through efficiently allocating capital sources to enterprises, facilitating risk management, scrutinizing business performance, and reducing costs of transferring resources (Camba \& Camba, 2019; Levine,

*This research is funded by University of Economics and Law, Vietnam National University Ho Chi Minh City, Vietnam.

${ }^{* *}$ First Author and Corresponding Author. Vice Director, Institute for Development and Research in Banking Technology, 1 University of Economics and Law, 2 Vietnam National University-HCM, Ho Chi Minh City, Vietnam [Postal Address: 669 National Route 1A, Quarter 3, Linh Xuan Ward, Thu Duc District, Ho Chi Minh City, 700000, Vietnam] Tel: (+84) 909.224.879. Email: sonth@uel.edu.vn ${ }^{* * *}$ Research Fellow, Institute for Development and Research in Banking Technology, 1 University of Economics and Law, 2 Vietnam National University-HCM, Ho Chi Minh City, Vietnam

() Copyright: The Author(s)

This is an Open Access article distributed under the terms of the Creative Commons Attribution NonCommercial License (https://creativecommons.org/licenses/by-nc/4.0/) which permits unrestricted noncommercial use, distribution, and reproduction in any medium, provided the original work is properly cited.
1997; Merton, 1995; Zhang \& Yin, 2018). However, the financial development might also negatively effect financial institutions and the financial system, thus causing financial instability or even financial crisis (Demirguc-Kunt \& Detragiache, 1998). Previous financial crises, especially in South-East Asia (1997-1998), highlighted the existence of the relationship between business cycles and bank risk. The relation between the business cycle and bank risk is particularly important in the case of emerging markets since business and financial cycles are often more pronounced in emerging markets than those in advanced countries (Claessens, Kose, \& Terrones, 2012).

We use banking sector development (measured as the ratio of domestic credit provided

by banking sector to GDP) and stock market development (measured as the ratio of the market capitalization of stock markets to GDP) as proxies for financial development. Bank risk is measured by Zscore and non-performing loans (Demirgüç-Kunt, Detraghiache, \& Tressel, 2008; Demirgüc-Kunt \& Huizinga, 2010; Köhler, 2015; Laeven \& Levine, 2009). In this study, we analyze the joint effects of the business cycle and financial development on bank risk. 
Because the banking sector plays a primary role in a country's economy, it is important to verify whether the phase of business cycles not only has a direct effect on bank risk, but also moderates the effect of financial development on bank risk.

Using an unbalanced panel sample of 95 publicly listed commercial banks in six South-East Asian countries over a 15-year period between 2004 and 2018, we address two fundamental questions: First, is financial development significantly associated with bank risk? Second, is the relation between financial development and bank risk based on the phase of business cycles?

This paper contributes to existing literature in two important ways. First, in terms of scientific and practical values, our paper contributes to the growing empirical studies on the relation between financial development and bank risk. In contrast to previous studies closest to ours (Vithessonthi, 2014a, 2014b) which focused on bank capital or bank revenue diversification as risk proxies, we rely on Z-score and non-performing loans (NPLs) as main indicators for bank risk. The Z-score has been widely used in the recent literature for measuring bank risk (BaselgaPascual, Trujillo-Ponce, \& Cardone-Riportella, 2015; Demirgüc-Kunt \& Huizinga, 2010; Köhler, 2015; Laeven \& Levine, 2009). Zscore is negatively correlated with bank risk; the higher its value, the lower the bank risk (Laeven \& Levine, 2009). NPLs is used as a measurement of bank soundness (Demirgüç-Kunt et al., 2008) and hence can be used as a proxy for bank risk (Delis \& Kouretas, 2011; Fiordelisi, Marques-Ibanez, \& Molyneux, 2011). A higher (lower) value for NPLs indicates a higher (lower) bank risk level. Different measures may present diverse aspects of bank risk, so our employment of the two new indicators should bring useful insights into the literature on the link between financial development and bank risk.

Second, we add to the business cycle literature. Several studies focused on the relationship between business cycle and bank behaviour especially for the case of developed countries and relatively little research has been conducted for the case of emerging countries (Saadaoui, 2014). In this study, we offer a possible explanation of the cyclical behavior of bank risk in South East Asia countries. This paper also helps extend Vithessonthi (2014a, 2014b) in that the latter study only examines the impact of financial development on bank risk. We contribute to the current literature by updating the data to the most updated with longer horizon (2004-2018) and examining the joint effects of the business cycle and financial development on bank risk. We further provide robustness tests to ascertain the findings in the current study.

We find that stock market development is positively associated with bank stability (measured as Zscore), after controlling for macro-level and firm-level variables, and is negatively associated with level of bank's NPLs, suggesting that stock market development lowers bank risk. While the measure of banking sector development is not associated with bank stability and level of bank's NPLs. When examining the joint effect of the business cycle and financial development on bank risk, however, we find that the phase of business cycles generally has no direct effect on bank risk.

\section{Literature Review}

This section summarizes the empirical literature focusing on: (1) financial development and bank risk and (2) business cycle and bank risk. Demirgüç-Kunt and Maksimovic (1996), Levine (1997), Rajan and Zingales (1998) and Ndikumana (2005) found that financial market development positively impacts real economic activities in an economy (investment, employment, productivity, economic growth, etc.). By efficient allocation of capital sources, financial intermediaries' performance is more effectual besides diminishing cost of capital, and also financial development would better economic growth. Howerver, few studies have been conducted to clarify the effect of financial development on bank risk (Vithessonthi \& Tongurai, 2016). Previous studies show that financial development can have positive as well as negative effects. Williams and Nguyen (2005) found that financial development through banking system liberalization in South-East Asian countries enhances efficiency in its operation over the period between 1990 and 2003, and banks help lower financial barriers and boost firm investments. Espenlaub, Khurshed, and Mohamed (2012) find that the liberalization of the banking sector can reduce the moral hazard between banks and connected firms.

On the contrary, some studies highlighted the negative effect of financial development on banking institutions and financial system. Financial development may be conducive to increased instability within the financial system if financial intermediaries are involved in more risky activities, subject to a credit boom, which provokes a potential financial crisis. Ruiz-Porras (2009) believed that financial development would incur the increased risk of bank failures, whereas Festić, Kavkler, and Repina (2011) pinpointed the negative effect of credit growth on bank's asset quality (measured by non-performing loans as a ratio to total assets). From another perspective, Eichengreen and Arteta (2002) argued that financial liberalization encourages financial intermediaries to engage themselves in risky activities, thus increasing bank risk. Demirgüç-Kunt and Detragiache (1998) and Glick and Hutchison (1999) found a positive relation between financial liberalization and bank risk. Stiglitz (2000) also shows that financial 
liberalization process in emerging economies is a source of banking and/or financial crisis. Cubillas and González (2014) investigate the effects of financial liberalization on risk of 4,333 banks in 83 countries, they find that the liberalization increases bank risk-taking in both developed and developing countries.

Vithessonthi (2014a) confirmed the effect of financial development, which tends to

increase risk (measured by banks' capital) of 52 banks in five South-East Asian countries for the

1990-2012 period. In a similar study, Vithessonthi (2014b) reasoned that development of financial

market negatively relates to bank risk in Thailand. Stock market development has a

tendency to reduce the risk, whereas banking sector development can lead to higher levels

of instability via reduced capital yet increased beta coefficient of the bank. Hamid, Azmi, and Ali (2019) examine the impact of financial development on bank risktaking from countries with dual-banking systems. The results suggest that the impact of financial development on bank capitalization is heterogeneous across Islamic and conventional commercial banks. Additionally, bank risk is found to be countercyclical, suggesting that bank risk increases in good times.

Bank risk also depends significantly on the business cycle (Bikker \& Metzemakers, 2005; Takasu \& Nakano, 2019). The existing literature, which focuses on either the effect of business cycle on lending, bank capital and on bank stability or cyclical behavior of bank risk. Bank credit would be positively related with the business cycle. Claessens et al. (2012) show that the rapid credit growth tends to amplify the economic expansions. Apostoaie and Percic (2014) confirm a positive relation between the credit cycle and the business cycle in the 12 European countries. Credit risk of banks is linked to the phase of the business cycle (Bikker \& Metzemakers, 2005).

At the time of economic downturns, the non-performing loans tend to increase whereas when there is an economic boom; banks increase their risk exposure by expanding their loans. The business cycle also has the influence on risk level and ability of raising capital easily (Lindquist, 2004; Van Roy, 2008). Shim (2013), using U.S. bank holding company data during the period 1992:Q1-2011:Q3, finds a negative co-movement between business cycle and capital buffer, it indicates that banks increase capital as economic conditions worsen. However, Guidara, Lai, Soumare, and Tchana (2013), who note that bank capital buffer had a positive co-movement with business cycles in research using quarterly financial statements and stock market data from 1982 to 2010 for the six largest Canadian banks. Ben Bouheni and Hasnaoui (2017) find that the bank risk is procyclical, meaning that during economic upturns, bank risk decreases, but during downturns, bank risk increases. In addition, this study shows that lending activity increases bank risk-taking while rising capital requirements ensure financial stability.

The main purpose of this study is to test empirically the existence of a relationship between financial development, business cycle and bank risk behaviour in South-East Asian countries. Based on these arguments we expect that the financial development has a link on the banks' risk profile because of both potential negative and positive links. In addition, bank risk-taking may move procyclically or countercyclically over the business cycle. If the relation between financial development and bank risk is based on the phase of business cycle, we should observe joint effect of the business cycle and financial development on bank risk. This leads to our following testable hypotheses:

H1: Financial sector development and bank risk are related. H2: The link between financial sector development and bank risk depends on the phase of business cycle.

\section{Data and Methodology}

The data in this study comprise bank-level and macrolevel data from 2004 to 2018. We collect all the listed banks in six countries in the South East Asian region, and remove those that do not have observations, finally creating a sample of a number of 95 banks. The macro-level data are retrieved from World Bank Indicators.

We estimate the model with one-period lagged explanatory variables with panel OLS regression to reduce the likelihood of encountering the possible endogeneity issue emanating from reverse-causality relationship (Vithessonthi \& Tongurai, 2016). We refrain from using fixed effects model to avoid the loss of degree of freedom which may account for about 10 per cent of the total observations in this study. The robust standard errors are used to correct for heteroskedasticity issue. We further provide robustness check to our findings by resorting to several proxies for bank risk.

\subsection{Model Specification}

To test our main predictions that there exists the effect of financial development on bank risk and that business cycles moderate this relationship, we use the model based on the relation between financial development and bank risk as represented in Equation (1). The model in Equation (1), which we refer to as the 'Interaction model', allows us to consider the joint effects of business cycle and financial development. Financial development may affect banks risk depending on the specific business cycle phase, and the 
coefficient $\alpha_{3}$ in Equation (1) would indicate whether the effect of financial development on bank risk depends on the business cycle.

$$
\begin{array}{r}
\operatorname{BankRisk}_{\mathrm{i}, \mathrm{t}+1}=\alpha_{0}+\alpha_{1} \cdot \mathrm{FD}_{\mathrm{i}, \mathrm{t}}+\alpha_{2} \cdot \mathrm{CYCLE}_{\mathrm{i}, \mathrm{t}}+\alpha_{3} \cdot \mathrm{FD}_{\mathrm{i}, \mathrm{t}} \mathrm{x} \\
\mathrm{CYCLE}_{\mathrm{i}, \mathrm{t}}+\alpha_{4} \cdot \mathrm{B}_{\mathrm{i}, \mathrm{t}}+\alpha_{5} \cdot \mathrm{C}_{\mathrm{i}, \mathrm{t}}+\varepsilon_{\mathrm{i}, \mathrm{t}}
\end{array}
$$

where BankRisk $\mathrm{i}_{\mathrm{i}, \mathrm{t}+1}$ denotes the variable used to measure the risk of bank $\mathrm{i}$ at year $\mathrm{t}+1$. Bank risk is measured by Zscore and NPLs (Baselga-Pascual et al., 2015; DemirgüçKunt et al., 2008; Demirgüc-Kunt \& Huizinga, 2010; Köhler, 2015; Laeven \& Levine, 2009). Zscore is estimated in consistent with Köhler (2015):

$$
\text { Score }_{i t}=\frac{R O A_{i t}+E Q T A_{i t}}{S_{R O A_{i p}}}
$$

where $E Q T A_{i t}$ is ratio of equity capital to total assets of bank $i$ in year t, and $S_{R O A_{i p}}$ is standard deviation of ROA of bank $i$ in surveyed period $p$. Zscore is negatively correlated with bank risk; the higher its value, the lower the bank risk (and, conversely, the lower its value, the higher the bank risk).

Following previous studies (e.g. Louzis, Vouldis, \& Metaxas, 2012), we use the ratio of non-performing loans/total loans as a measurement of NPLs. In line with the literature, our financial development $\left(\mathrm{FD}_{\mathrm{it}}\right)$ measures of a country are based on two dimensions of financial development: stock market development and banking sector development (Chinn \& Ito, 2006; Gimet \& Lagoarde-Segot, 2011, 2012; Vithessonthi, 2014a, 2014b). Banking sector development - $\mathrm{BSD}_{\text {it }}$ (measured as the ratio of domestic credit provided by banking sector to GDP) and stock market development - $\mathrm{SMD}_{\text {it }}$ (measured as the ratio of the market capitalization of stock market to GDP). Consistent with following studies (e.g., Brockman, Liebenberg, \& Schutte, 2010; Shim, 2013) discussing the business cycle, we measure the phase of the business cycle $\left(\mathrm{CYCLE}_{\mathrm{i}, \mathrm{t}}\right)$ using real GDP growth. B is a set of independent bank-level variables, and $\mathrm{C}$ is a country-level macroeconomic variable (TRADE) to further control for the effect of economic openness. The countries included in the sample are those that have relied on high levels of trade openness, which could affect bank risk significantly (Vithessonthi, 2014a, 2014b).

Based on earlier literature, we include a series of banklevel variables (B group of variables) that have been found to affect bank risk (Baselga-Pascual et al., 2015) as follows (see Table 1):

Revenue diversification: Revenue diversification is measured by the share of non-interest income to total income. There are some studies showing that diversification in banks business model do not reduce bank risk. DeYoung and Torna (2013) find that nontraditional banking activities increase the probability of bank failure. Prior work (see e.g. Demirgüc-Kunt \& Huizinga, 2010; Stiroh, 2004) provides empirical evidence on the positive relation between revenue diversification and bank risk. So, we expect a positive impact of bank diversification on bank risk.

Bank size: Bank size is an important variable in determining bank risk. Louzis et al. (2012) argued that major banks have less risk. Several authors show the existence of a negative relationship between size and bank risk (Baselga-Pascual et al., 2015). Gul and Cho (2019) also suggest that risk is negatively related to firm size. Thus, bank risk may be negatively impacted by size. Bank size (Size) is computed as the natural logarithm of end-of-year total assets.

Liquidity: liquidity of a bank is measured by ratio of bank cash to total deposits (LIQ). This indicator shows the ability to ensure the bank liquidity and soundness, thus the higher the ratio, the lower level of bank risk (Shim, 2013; Vithessonthi, 2014a, 2014b).

Operational efficiency: Operational efficiency is measured by the cost-to-income ratio (CIR). The effect of operational efficiency is ambiguous. Under the 'skimping hypothesis' of Berger and DeYoung (1997), banks will have an increasing number of non-performing loans if banks devote less resources to monitor loan. This implies a negative effect of cost efficiency on bank risk. On the contrary, under the 'bad management I' hypothesis, Louzis et al. (2012) state that higher cost inefficiency could increase nonperforming loans.

Table 1: Description of independent variables

\begin{tabular}{|l|l|l|l|}
\hline Variable & \multicolumn{1}{|c|}{ Meaning } & \multicolumn{1}{|c|}{$\begin{array}{c}\text { Measurement } \\
\text { method }\end{array}$} & Expected sign \\
\hline BRD & $\begin{array}{l}\text { Revenue } \\
\text { diversification }\end{array}$ & $\begin{array}{l}\text { Rate of non-interest } \\
\text { income-to-total } \\
\text { income }\end{array}$ & + \\
\hline SIZE & Bank size & $\begin{array}{l}\text { Natural logarithm } \\
\text { of end-of-year total } \\
\text { assets }\end{array}$ & - \\
\hline LIQ & Liquidity & $\begin{array}{l}\text { Ratio of bank cash } \\
\text { to total deposits }\end{array}$ & - \\
\hline CIR & $\begin{array}{l}\text { Operational } \\
\text { efficiency }\end{array}$ & $\begin{array}{l}\text { Cost-to-income } \\
\text { ratio }\end{array}$ & $+/-$ \\
\hline ROA & Profitability & $\begin{array}{l}\text { Net income divided } \\
\text { by total assets }\end{array}$ & - \\
\hline TRADE & Trade openness & $\begin{array}{l}\text { Ratio of the sum of } \\
\text { total exports and } \\
\text { imports to GDP }\end{array}$ & $+/-$ \\
\hline CYCLE & Business cycle & GDP growth rate & $+/-$ \\
\hline
\end{tabular}

Profitability: Profitability is measured by return on assets (ROA), i.e. net income divided by total assets. Under the 'bad management' hypothesis of Berger and DeYoung (1997), highly profitable banks have less incentives to 
engage in high-risk activities, thereby reducing bank risk.

We use trade openness (TRADE), which is measured as the ratio of the sum of total exports and imports to GDP (in \%), to control for macroeconomic effects on bank risk. The effect of trade openness on bank risk is theoretically ambiguous. Trade openness may have a negative impact on bank risk, for instance, banks in countries with higher trade openness may diversify their loan portfolio between internationally trading firms and domestic firms (Ashraf, Arshad, \& Yan, 2017). On the contrary, trade openness may have a positive impact on bank risk-taking due to higher competition and volatility that may follow (Bushman, Hendricks, \& Williams, 2014; Loayza \& Rancière, 2006).

\section{Empirical Results}

\subsection{Descriptive Statistics}

BRD has the value of 0.1858 , or about 20 per cent of the total income is non-interest one. LIQ is 0.17 or cash is 17 per cent of the total deposits (see Table 2). The mean costto-income ratio is pretty low at about four per cent, but the maximum value could reach 65 per cent. Trade to GDP ratio's mean ratio is 102 per cent, which is high compared to other countries such as South American ones (Vithessonthi \& Tongurai, 2016). The ROA value is about one per cent, which is pretty low as opposed to that of the sample banks in Vithessonthi and Tongurai (2016), which reaches $3.64 \%$. Importantly, financial development as indicated by SMD and BSD is much higher than those countries in South America. The average economic growth rate in the area is 5.35 per cent, which is quite encouraging.

Table 2: Descriptive statistics

\begin{tabular}{|c|c|c|c|c|c|}
\hline Variable & Obs & Mean & Std. Dev. & Min & Max \\
\hline BRD & 1,200 & 0.1858 & 0.1326 & -0.4855 & 0.7364 \\
\hline LIQ & 1,200 & 0.1703 & 0.2058 & 0.0001 & 6.3417 \\
\hline CIR & 1,192 & 0.0359 & 0.2576 & -4.3555 & 0.6476 \\
\hline SIZE & 1,200 & 22.4546 & 1.9977 & 14.7152 & 26.7251 \\
\hline TRADE & 1,253 & 102.2742 & 72.0887 & 37.4213 & 437.3270 \\
\hline ROA & 1,200 & 0.0104 & 0.0139 & -0.2080 & 0.0822 \\
\hline BSD & 1,253 & 60.9418 & 38.3170 & 23.8680 & 133.3060 \\
\hline SMD & 1,221 & 68.7801 & 47.3183 & 12.4743 & 297.9832 \\
\hline CYCLE & 1,253 & 5.3514 & 1.6546 & -1.5135 & 14.5256 \\
\hline
\end{tabular}

\subsection{Regression Results}

This section presents the empirical estimates of the regression specifications presented in section 3. From Table 3 , the impact of stock market development (the ratio of the market capitalization of stock markets to GDP) on Zscore is significantly positive at the $1 \%$ level, whereas its effect on NPLs is significantly negative at the $1 \%$ level. The effect of banking sector development on both measures of bank risk is insignificant. In other words, stock market development lowers bank risk, whereas banking sector development does not have any effect on it. These results are different to that of Vithessonthi (2014a, 2014b) but in line with our expectations. This could be due to our choice of bank risk proxies. For instance, The Z-score is an indicator of insolvency risk, which has also been frequently used in the empirical literature (Baselga-Pascual et al., 2015; Demirgüc-Kunt \& Huizinga, 2010; Köhler, 2015; Laeven \& Levine, 2009).

Table 3: Bank risk and financial development.

\begin{tabular}{|c|c|c|c|c|}
\hline Variables & \multicolumn{2}{|c|}{$\begin{array}{c}\text { (1) } \\
\text { Zscore }\end{array}$} & \multicolumn{2}{|c|}{$\begin{array}{c}\text { (2) } \\
\text { NPLs }\end{array}$} \\
\hline BSD & 0.0661 & $(0.0616)$ & -0.0001 & $(0.0001)$ \\
\hline SMD & $0.1361 * * *$ & $(0.0372)$ & $-0.0003 * * *$ & $(0.0001)$ \\
\hline CYCLE & -0.1377 & $(0.8403)$ & 0.0023 & $(0.0032)$ \\
\hline $\begin{array}{l}\text { BSD x } \\
\text { CYCLE }\end{array}$ & -0.0063 & $(0.0107)$ & 0.0000 & $(0.0000)$ \\
\hline $\begin{array}{l}\text { SMD x } \\
\text { CYCLE }\end{array}$ & 0.0008 & $(0.0049)$ & 0.0000 & $(0.0000)$ \\
\hline BRD & $-25.5061 * * *$ & $(0.7669)$ & $0.0767 * *$ & $(0.0383)$ \\
\hline SIZE & $2.8942 * * *$ & $(0.4192)$ & -0.0020 & $(0.0015)$ \\
\hline LIQUIDITY & $14.6538 * * *$ & $(1.4465)$ & $-0.0161 *$ & (0.0087) \\
\hline CIR & -1.3917 & $(4.0692)$ & -0.0055 & $(0.0126)$ \\
\hline ROA & $205.5053 * * *$ & (39.633) & $-1.7701 * *$ & $(0.7215)$ \\
\hline TRADE & -0.0124 & $(0.0168)$ & $0.0001 * * *$ & $(0.0000)$ \\
\hline CONSTANT & $-44.1303 * * *$ & (8.8088) & $0.1103 * * *$ & $(0.8640)$ \\
\hline $\mathrm{R}^{2}$ & 0.224 & & 0.148 & \\
\hline F value & $57.58 * * *$ & & $5.28 * * *$ & \\
\hline $\mathrm{N}$ & 1082 & & 915 & \\
\hline
\end{tabular}

Notes: $* * *$, and $* * *$ represent the significance levels at $10 \%, 5 \%$, and $1 \%$, respectively. Numbers in parentheses are standard errors.

Furthermore, Poghosyan and Cihak (2011) conclude that the impact of bank capitalization on bank distress seems to be less important compared to bank earnings and asset quality, which justifies our choice of the NPLs as a measure of bank risk. Thus, Hypothesis 1 is supported. Our results are in line with Vithessonthi and Tongurai (2016) who report a negative effect of stock market development on bank risk and no significant effect of stock market development on bank risk in the South American region. These findings indicate that the size of the stock market is an important determinant of bank risk in South-East Asian countries. As a consequence, we conclude that the increase in market capitalization leads to lower bank risk in SouthEast Asian economies. 
In all models, the coefficient on business cycle (CYCLE) is insignificant. We also find no evidence of the moderating effect of the business cycle (CYCLE) on the relation between financial development and bank risk. These results suggest that the phase of the business cycle does not moderate the effect of financial development on bank risk, thereby providing no support for Hypothesis 2. Our results are consistent with Vithessonthi (2016) who reports the business cycle does not moderate the effect of financial development on bank risk in the South American region.

Revenue diversification seems to be a strong driving force behind bank risk. In other

words, diversification activities increase bank risk as measured by the Z-score and NPLs. The positive effect of the revenue diversification on bank risk is accordance with several studies (e.g., DeYoung \& Torna, 2013; Stiroh, 2004 for developed countries and Demirgüc-Kunt \& Huizinga, 2010 for a sample of 101 countries). The positive effect of bank size on Zscore suggests that bank risk is negatively impacted by the size. This indicates that bigger banks appear to be less risky compared with smaller banks - this is consistent with Louzis et al. (2012) and Baselga Pascual et al. (2015). However, the impact of bank size on NPLs is insignificant. Profitability and liquidity seem to reduce bank risk. This evidence supports the 'bad management' hypothesis of Berger and DeYoung (1997) which suggests that highly profitable banks have fewer incentives to engage in high-risk activities. These findings are consistent with Louzis et al. (2012), Vithessonthi (2014a, 2014b) and Hamid et al. (2019). Finally, trade openness increases bank risk as measured by NPLs, the findings suggest that banks appear to decrease asset quality due to higher competition and volatility (Bushman et al. 2014; Loayza \& Rancière, 2006). These results are different to that of Vithessonthi and Tongurai (2016).

\section{Robustness Check}

To ascertain the aforementioned findings, we conduct a robustness checks. We re-estimate our models changing the bank risk variables, and the use of different proxies for risktaking provides more insights into bank risk factors (Ben Bouheni, Ben Ameur, Jawadi, \& Idi Cheffou, 2016).

Table 4: Robustness checks: alternative proxies of bank risk

\begin{tabular}{|c|c|c|c|c|c|c|}
\hline \multirow{2}{*}{$\begin{array}{c}\text { Variables } \\
\text { BSD }\end{array}$} & \multicolumn{2}{|c|}{$\begin{array}{c}(1) \\
\text { RAROA }\end{array}$} & \multicolumn{2}{|c|}{$\begin{array}{c}\text { (2) } \\
\text { RACAR }\end{array}$} & \multicolumn{2}{|c|}{$\begin{array}{c}\text { (3) } \\
\text { LLPs }\end{array}$} \\
\hline & -0.0018 & $(0.0064)$ & 0.0679 & $(0.0562)$ & 0.0000 & $(0.0001)$ \\
\hline SMD & $0.0116^{* *}$ & $(0.0046)$ & $0.1245^{* * *}$ & $(0.0335)$ & $-0.0002 * * *$ & $(0.0000)$ \\
\hline CYCLE & -0.0445 & $(0.0988)$ & -0.0932 & $(0.7614)$ & $0.0060^{* * *}$ & $(0.0019)$ \\
\hline BSD x CYCLE & 0.0004 & $(0.0012)$ & -0.0068 & $(0.0098)$ & $-0.0001 * * *$ & $(0.0000)$ \\
\hline SMD x CYCLE & -0.0003 & $(0.0006)$ & 0.0010 & $(0.0044)$ & 0.0000 & $(0.0000)$ \\
\hline BRD & $-3.1126 * * *$ & (1.1519) & -22.3936 & $(5.8918)$ & $0.1267^{* * *}$ & $(0.0487)$ \\
\hline SIZE & $0.6696^{* * *}$ & $(0.0472)$ & $2.2247 * * *$ & $(0.3862)$ & $0.0013 *$ & $(0.0008)$ \\
\hline LIQUIDITY & 0.2592 & $(0.1663)$ & $14.3946^{* * *}$ & $(1.3421)$ & -0.0102 & $(0.0098)$ \\
\hline CIR & -0.7621 & $(0.9352)$ & -0.6296 & $(3.2142)$ & 0.0221 & $(0.0173)$ \\
\hline $\mathrm{ROA}$ & $47.6427 * * *$ & $(8.8723)$ & $157.8626^{* * *}$ & (33.0075) & -0.8073 & $(0.5895)$ \\
\hline TRADE & 0.0000 & $(0.0022)$ & -0.0124 & $(0.0151)$ & $0.0001 * *$ & $(0.0000)$ \\
\hline CONSTANT & $-12.5961 * * *$ & (1.0529) & $-31.5342 * * *$ & $(8.0748)$ & 0.0154 & $(0.0171)$ \\
\hline $\mathrm{R}^{2}$ & 0.3569 & & 0.2028 & & 0.1202 & \\
\hline F value & $60.61 * * *$ & & $54.13 * * *$ & & $11.40 * * *$ & \\
\hline $\mathrm{N}$ & 1082 & & 1082 & & 1015 & \\
\hline
\end{tabular}

Notes: $* * *$, and $* * *$ represent the significance levels at $10 \%, 5 \%$, and $1 \%$, respectively. Numbers in parentheses are standard errors.

We adopt Köhler's (2015) approach by which Zscore is decomposed into RAROA (risk-adjusted return on assets) and RACAR (risk-adjusted capital asset ratio), both of which are employed as alternative measures of bank risk (the higher values of RAROA and RACAR of the focal bank, the lower the bank risk):

$$
\begin{aligned}
& R A R O A_{i t}=\frac{R O A_{i t}}{S D R O A_{i p}} \\
& R A C A R_{i t}=\frac{E Q T A_{i t}}{S D R O A_{i p}}
\end{aligned}
$$


Another metric also used to proxy bank risk is the loan loss provisions ratio - LLPs (as a percentage of total loans). High loan loss provisions indicate high bank risk (BaselgaPascual et al., 2015; Chaibi \& Ftiti, 2015).

Overall, our basic findings are robust to different definitions of bank risk. In Table 4, we find that the results are similar to the main results in Table 3. For example, we find that stock market development exerts a significantly positive effect on RAROA and RACAR and its effect on LLPs is significantly negative at the $1 \%$ level, while the effect of banking sector development on alternative measures of bank risk is insignificant.

\section{Conclusion}

Using a sample of 95 publicly listed banks in the Southeast Asian countries, we analyze the joint effects of business cycle and financial development on bank risk and find that the degree of stock markets development (the ratio of the market capitalization of stock markets to GDP) is positively associated with the Zscore and is negatively associated with the NPLs, after controlling for macro-level and bank-level variables. The negative impact of financial development on bank risk by increasing banks' stabiliy (measured by Zscore) and reducing NPLs, however, this finding is different to that of Vithessonthi (2014a, 2014b). There is no evidence that these effects are moderated by the phase of business cycles, and this result is in line with Vithessonthi and Tongurai (2016). In other words, the phase of business cycles generally has no direct effect on bank risk, except for the case when the dependent variable is loan loss provisions. Our findings suggest the reaffirmation of the importance of bank monitoring in order to reduce excessive risk-taking of the banks (e.g., holding low quality of bank assets or increasing non-core banking activities).

\section{References}

Apostoaie, C., \& Percic, S. (2014). Credit cycles and business cycles in twenty EU economies. Procedia Economics and Finance, 15, 1055-1064. https://doi.org/10.1016/S22125671(14)00669-8.

Ashraf, B. N., Arshad, S., \& Yan, L. (2017). Trade Openness and Bank Risk-Taking

Behavior: Evidence from Emerging Economies. Journal of Risk and Financial Management, 10(3), 1-18. https://doi.org/10.3390/jrfm10030015.

Baselga-Pascual, L., Trujillo-Ponce, A., \& Cardone Riportella, C. (2015). Factors influencing bank risk in Europe: Evidence from the financial crisis. The North American Journal of Economics and Finance, 34, 138-166. https://doi.org/10.1016/j.najef.2015.08.004.
Ben Bouheni, F., Ben Ameur, H., Jawadi, F., \& Idi Cheffou, A. (2016). Do regulatory and supervisory reforms affect European bank stability: further evidence from panel data. Bankers, Markets \& Investors, 141, 5-17.

Ben Bouheni, F., \& Hasnaoui, A. (2017). Cyclical behavior of the financial stability of Eurozone commercial banks. Economic Modelling, https://doi.org/10.1016/j.econmod.2017.02.018.

Berger, A. N., \& DeYoung R. (1997). Problem loans and cost efficiency in commercial banks. Journal of Banking \& Finance, 21(6), 849-870. https://doi.org/10.1016/S03784266(97)00003-4.

Bikker, J. A., \& Metzemakers, P. A. J. (2005). Bank provisioning behaviour and procyclicality. Journal of International Financial Markets, Institutions and Money, 15, 141-157. https://doi.org/10.1016/j.intfin.2004.03.004.

Brockman, P., Liebenberg, I., \& Schutte, M. (2010). Comovement, information production, and

the business cycle. Journal of Financial Economics, 97, 107129. https://doi.org/10.1016/j.jfineco.2010.03.008.

Bushman, R. M., Hendricks, B. E., \& Williams, C. D. (2014). The Effect of Bank Competition on Accounting Choices, Operational Decisions and Bank Stability: A Text Based Analysis. Working Paper, UNC and Michigan, Ann Arbor, MI, USA.

Camba, A. C., \& Camba, A. L. (2019). The dynamic relationship of domestic credit and stock market liquidity on the economic growth of the Philippines. Journal of Asian Finance, Economics and Business, 7(1), 37-46. https://doi.org/10.13106/jafeb.2020.vol7.no1.37

Chaibi, H., \& Ftiti, Z. (2015). Credit risk determinants: Evidence from a cross-country study. Research in International Business and Finance, 33, 1-16. https://doi.org/ 10.1016/j.ribaf.2014.06.001

Chinn, M. D., \& Ito, H. (2006). What matters for financial development? Capital controls, institutions, and interactions. Journal of Development Economics, 81, 163-192. https://doi.org/10.1016/j.jdeveco.2005.05.010.

Claessens, S., Kose, M., \& Terrones, M. (2012). How do business and financial cycles interact. Journal of International Economics, 87(1), 178-190. doi:10.1016/j.jinteco.2011.11.008.

Cubillas, E., \& González, F. (2014). Financial liberalization and bank risk-taking: International evidence. Journal of Financial Stability, 11, 32-48. https://doi.org/10.1016/j.jfs.2013.11.001.

Delis, M. D., \& Kouretas, G. P. (2011). Interest rates and bank risk-taking. Journal of Banking \&

Finance, 35 ,

840-855. https://doi.org/10.1016/j.jbankfin.2010.09.032.

Demirguc-Kunt, A., \& Detragiache, E. (1998). Financial liberalization and financial fragilit (IMF Working Paper No. 98/83).

Demirgüç-Kunt, A., Detragiache, E., \& Tressel, T. (2008). Banking on the Principles: Compliance with Basel Core Principles and Bank Soundness. Journal of Financial Intermediation, 17, 511-42. https://doi.org/10.1016/j.jfi.2007.10.003.

Demirgüc-Kunt, A., \& Huizinga, H. (2010). Bank activity and funding strategies: The impact on risk and returns. Journal of Financial Economics, 98(3), 626-650. 
https://doi.org/10.1016/j.jfineco.2010.06.004.

Demirgüç-Kunt, A., \& Maksimovic, V. (1996). Stock market development and financing choices of firms. The World Bank Economic Review, 10(2), 341 -369.

DeYoung, R., \& Torna, G. (2013). Nontraditional banking activities and bank failures during the financial crisis. Journal of Financial Intermediation, 22(3), 397-421. https://doi.org/10.1016/j.jfi.2013.01.001.

Eichengreen, B., \& Arteta, C. (2002). Banking crises in emerging markets: Presumptions and evidence. In M. Skreb, \& I. Blejer (Eds.), Financial policies in emerging markets. Cambridge, MA: MIT Press.

Espenlaub, S., Khurshed, A., \& Mohamed, A. (2012). IPO survival in a reputational market. Journal of Business Finance and Accounting, 39(3-4), 427-463

Festić, M., Kavkler, A., \& Repina, S. (2011). The macroeconomic sources of systemic risk in the banking sectors of five new EU member states. Journal of Banking \& Finance, 35(2), 310-322. https://doi.org/10.1016/j.jbankfin.2010.08.007.

Fiordelisi, F., Marques-Ibanez, D., \& Molyneux, P. (2011). Efficiency and risk in European

banking. Journal of Banking \& Finance, 35, 1315-1326. https://doi.org/10.1016/j.jbankfin.2010.10.005.

Gimet, C., \& Lagoarde-Segot, T. (2012). Financial sector development and access to finance. Does size say it all? Emerging Markets Review, 13, 316-337. https://doi.org/10.1016/j.ememar.2011.11.002.

Glick, R., \& Hutchison, M. (1999). Banking and currency crises: How common are twins (Federal Reserve Bank of San Francisco, Pacific Basin Working Paper Series, Working Paper No. PB99-07).

Guidara, A., Lai, V.S., Soumaré, I., \& Tchana, T.F. (2013). Banks' capital buffer, risk and performance in the Canadian banking system: impact of business cycles and regulatory changes. Journal of Banking and Finance. 37, 3373-3387. https://doi.org/10.1016/j.jbankfin.2013.05.012.

Gul, S., \& Cho, H. (2019). Capital structure and default risk: Evidence from Korean stock market. The Journal of Asian Finance, Economics and Business, 6(2), 15-24. https://doi.org/10.13106/jafeb.2019.vol6.no2.15

Hamid, B, A., Azmi, A., \& Ali, M. (2019). Bank Risk and Financial Development: Evidence Form Dual Banking Countries. Emerging Markets Finance and Trade, 1-19. https://doi.org/10.1080/1540496X.2019.1669445.

Köhler, M. (2015). Which banks are more risky? The impact of business model on bank stability. Journal of Financial Stability, 16, 195-212. https://doi.org/10.1016/j.jfs.2014.02.005.

Laeven, L., \& Levine, R. (2009). Bank governance, regulation and risk taking. Journal of Financial Economics, 93(2), 259-275. https://doi.org/10.1016/j.jfineco.2008.09.003.

Levine, R. (1997). Financial development and economic growth: Views and agenda. Journal of Economic Literature, 35, 688726.

Lindquist, K.G. (2004). Banks' buffer capital: how important is risk. Journal of International Money and Finance, 23(3), 493513. https://doi.org/10.1016/j.jimonfin.2004.01.006.

Loayza, N. V., \& Ranciere, R. (2006). Financial development, financial fragility, and growth. Journal of Money, Credit and
Banking, 38, 1051-1076.

Louzis, D. P., Vouldis, A. T., \& Metaxas, V. L. (2012). Macroeconomic and bank-specific determinants of nonperforming loans in Greece: A comparative study of mortgage, business and consumer loan portfolios. Journal of Banking \& Finance, 36(4), 1012-1027.

https://doi.org/10.1016/j.jbankfin.2011.10.012.

Merton, R. C. (1995). A functional perspective of financial intermediation. Financial Management, 24(2), 23-41.

Ndikumana, L. (2005). Financial development, financial structure, and domestic investment: International evidence. Journal of International Money and Finance, 24(4), 651 -673. https://doi.org/10.1016/j.jimonfin.2005.03.006.

Poghosyan, T., \& Čihak, M. (2011). Determinants of bank distress in Europe: evidence from a new data set. Journal of Financial Services Research, 40, 163-184. https://doi.org/10.1007/s10693-011-0103-1.

Rajan, R. G., \& Zingales, L. (1998). Financial dependence and growth. The American Economic Review, 88, 559-586.

Ruiz-Porras, A. (2009). Financial structure, Financial development and banking fragility:

International evidence. Analisis Economico, 24(56), 147-173.

Saadaoui, Z. (2014). Business cycle, market power and bank behaviour in emerging countries. International Economics, 139, 109-132. https://doi.org/10.1016/j.inteco.2014.04.001.

Shim, J. (2013). Bank capital buffer and portfolio risk: the influence of business cycle and revenue diversification. Journal of Banking \& Finance, 37, 761-772. https://doi.org/10.1016/j.jbankfin.2012.10.002.

Soedarmono, W., Machrouh, F., \& Tarazi, A (2011). Bank market power, economic growth and financial stability: Evidence from Asian banks. Journal of Asian Economics, 22, 460-470. https://doi.org/10.1016/j.asieco.2011.08.003.

Stiglitz, J. E., (2000). Capital market liberalization, economic growth, and instability. World Development, 28, 1075-1086. https://doi.org/10.1016/S0305-750X(00)00006-1.

Stiroh, K. J. (2004). Diversification in banking: Is noninterest income the answer? Journal of Money, Credit, and Banking, 36(5), 853-882.

Takasu, Y., \& Nakano, M. (2019). Conservative loan loss allowance and bank lending. Journal of Asian Finance, Economics and Business, 6(3), 9-18. https://doi.org/10.13106/jafeb.2019.vol6.no3.9

Uhde, A., \& Heimeshoff, U. (2009). Consolidation in banking and financial stability in Europe: Empirical evidence. Journal of Banking and Finance, 33(7), 1299-1311. https://doi.org/10.1016/j.jbankfin.2009.01.006.

Van Roy, P. (2008). Capital requirements and bank behavior in the early 1990s: Cross country evidence. International Journal of Central Banking, 4(3), 29- 60.

Vithessonthi, C. (2014a). The effect of financial markets development on bank risk: Evidence from Southeast Asian countries. International Review of Financial Analysis, 35, 249260. https://doi.org/10.1016/j.irfa.2014.10.005.

Vithessonthi, C. (2014b). Financial markets development and bank risk: Experience from Thailand during $1990-2012$. Journal of Multinational Financial Management, 27, 67- 88. https://doi.org/10.1016/j.mulfin.2014.05.003.

Vithessonthi, C., \& Tongurai, J. (2016). Financial Markets 
Development, Business Cycles, and Bank Risk in South America. Research in International Business and Finance, 36, 472-484. https://doi.org/10.1016/j.ribaf.2015.10.012.

Williams, J., \& Nguyen, N., (2005). Financial liberalisation, crisis, and restructuring: A comparative study of bank performance and bank governance in South East Asia. Journal of Banking \& Finance, 29(8-9), 2119-2154. https://doi.org/10.1016/j.jbankfin.2005.03.011.

Zhang, R., \& Yin, H. (2018). Regional financial development, firm heterogeneity and investment efficiency. Journal of Asian Finance, Economics and Business, 5(4), 73-83. http://doi.org/10.13106/jafeb.2018.vol5.no4.73 